\title{
Pengaruh Model Pembelajaran Inkuiri Terhadap Kemampuan Beprikir Kritis dan Karakter Siswa Kelas VII SMP Negeri 3 Langsa
}

\author{
Aburizal Bakri $^{1}$, Mulyono $^{2}$, Edi Syahputra ${ }^{2}$
}

\begin{abstract}
ABSTRAK
Penelitian ini bertujuan untuk menganalisis dan mengetahui 1) Pengaruh model pembelajaran inkuiri terhadap kemampuan berpikir kritis siswa kelas VII SMP Negeri 3 Langsa; 2) Pengaruh model pembelajaran inkuiri terhadap karakter siswa kelas VII SMP Negeri 3 Langsa; 3) Interaksi antara model pembelajaran dan KAM terhadap kemampuan berpikir kritis siswa kelas VII SMP Negeri 3 Langsa; 4) Interaksi antara model pembelajaran dan KAM terhadap karakter siswa kelas VII SMP Negeri 3 Langsa. Penelitian ini adalah penelitian kuasi eksperimen dengan pendekatyan kuantitatif. Pengambilan sampel pada penelitian ini dengan menggunakan teknik undian, dimanan kelas VII.2A sebagai kelas eksperimen dan kelas VII.5B sebagai kelas kontrol. Instrumen yang digunakan adalah tes kemampuan berpikir krtitis dan angket karakter siswa. Untuk pengujian hipotesis digunakan Anava dua jalur. Hasil penelitian menunjukkan bahwa 1) Terdapat pengaruh model pembelajaran inkuiri terhadap kemampuan berpikir kritis siswa kelas VII SMP Negeri 3 Langsa; 2) Terdapat pengaruh model pembelajaran inkuiri terhadap karakter siswa kelas VII SMP Negeri 3 Langsa; 3 ) Terdapat interaksi antara model pembelajaran dan KAM terhadap kemampuan berpikir kritis siswa kelas VII SMP Negeri 3 Langsa; 4) Tidak terdapat interaksi antara model pembelajaran dan KAM terhadap karakter siswa kelas VII SMP Negeri 3 Langsa
\end{abstract}

\section{Kata Kunci: Model Pembelajaran Inkuiri, Kemampuan Berpikir Kritis, Karakter Siswa}

\section{PENDAHULUAN}

Pembelajaran pada kurikulum 2013 memiliki tujuan untuk mencapai kemampuan berpikir tingkat tinggi atau High Order Thingking (HOT) sejak dini. Berpikir kritis merupakan perwujudan dari HOT (Rosmaiyadi, 2017). Keterampilan berpikir kritis diperlukan dalam matematika, karena memiliki peran yang sangat dominan dalam mendidik siswa. Siswa diharapkan memperoleh kemampuan untuk mengelola informasi agar dapat bertahan dalam keadaan yang selalu berubah, tidak pasti dan kompetitif (Simbolon, Manullang, Surya dan Syahputra, 2017).

Berpikir kritis merupakan bentuk berpikir yang perlu dikembangkan pada setiap siswa. Menurut Samosir (2018), berpikir kritis adalah proses mencari, memperoleh, mengevaluasi, menganalisis, mensintesis dan konseptualisasi informasi sebagai panduan untuk mengembangkan pemikiran seseorang dengan kesadaran diri, dan kemampuan untuk menggunakan informasi ini untuk menambah kreativitas dan mengambil risiko. Hal senada di yang diungkapkan oleh Temel (2014) Berpikir kritis adalah berpikir yang membantu dalam memecahkan masalah dan membuat penilaian. Berpikir kritis merupakan kemampuan berpikir tingkat tinggi, yang mendeskripsikan proses-

${ }^{1}$ Corresponding Author: Aburizal Bakri

SMP Negeri 3 Langsa, Kota Langsa, Aceh, Indonesia

E-mail: aboeriezalbakrie90@gmail.com

${ }^{2}$ Co-Author: Mulyono \& Edi Syahputra

Program Studi Pendidikan Matematika Universitas Negeri Medan, Medan, 2022, Indonesia proses interpretasi, analisis, evaluasi, inferensi, eksplanasi dan pengaturan diri. Kemampuan berpikir kritis diartikan sebagai pemikiran reflektif dan logis yang berfokus untuk memutuskan apa yang harus diyakini atau dilakukan (Putu Verawati, Wahyudi, Taufik, 2018).

Namun kenyataannya saat ini kemampuan berpikir kritis siswa dalam pembelajaran matematika masih rendah dan perlu ditingkatkan. Berdasarakan hasil penelitian yang dilakukan oleh Ayu Latifa, Putu Verawati, Harjono (2017) kemampuan berpikir kritis siwa rendah dikarenakan pada proses pembelajaran yang diterapkan selama ini belum mampu meningkatkan kemampuan berpikir kritis, karena latihan untuk peningkatan kemampuan tersebut belum dilakukan. Penyebab lainnya adalah karena model pembelajaran yang digunakan terkesan monoton dan kurang variatif.

Sundahry, Fitria, Rakimahwati (2018) menambahkan bahwa keterampilan berpikir kritis siswa yang belum berkembang salah satunya disebabkan oleh pembelajaran di sekolah yang tidak memberdayakan keterampilan berpikir kritis siswa. Faktanya bahwa peserta didik kurang mampu mengidentifikasi argumen. Peserta didik tidak memiliki pengalaman langsung secara nyata sebagai pemahaman dasar dari abstrak sehingga peserta didik kurang mampu mengidentifikasi logika mana yang salah. Peserta didik dalam diskusi diskusi kelompok kurang mampu membedakan informasi, pendapat, dan asumsi.

Hal di atas sejalan dengan hasil observasi awal yang penulis lakukan pada siswa kelas VIII SMP 
Negeri 3 Langsa pada materi bangun ruang. Pada saat siswa dihadapkan pada permasalahan yang berkaitan dengan kehidupan nyata yang menyangkut materi, siswa tidak merasa terdorong untuk bernalar dan berpikir lebih jauh bagaimana menyelesaikan masalah yang diberikan oleh guru, hal ini disebabkan karena penggunaan model pembelajaran yang kurang tepat, yang tidak membuat siswa terlibat aktif dalam proses pembelajaran.

Berdasarkan permasalahan di atas, maka dibutuhkan sebuah model pembelajaran yang dapat membuat siswa akttif dalam proses belajar matematika dan meningkatkan kemampuan berpikir kritisnya. Salah satu model pembelajaran yang dapat diterapkan oleh guru dalam proses pembelajaran matematika untuk meningkatkan kemampuan berpikir kritis adalah model pembelajaran inkuiri.

Sugianto, Suryandari, Age (2020) model pembelajaran inkuiri adalah rangkaian dari suatu pengkajian yang melibatkkan seluruh siswa agar berfikir secara teliti, analogis dan sistematis sehingga bisa memecahkan masalah yang dihadapinnya. Jadi siswa harus aktif pada saat pembelajaran berlangsung. Purwati (2016) menjelaskan pembelajaran inkuiri merupakan pembelajaran yang menuntut peserta didik untuk melakukan aktivitas seperti perencanaan investigasi, melakukan observasi, menganalisis, menafsirkan data, mengusulkan jawaban, merumuskan kesimpulan dan berkomunikasi, pada intinya siswa berperan aktif dalam mengikuti proses pembelajaran.

Berdasarkan penjelasan di atas disimpulkan bahwa model pembelajaran inkuiri dapat meningkatkan kemampuan berpikir kritis siswa, hal ini sejalan dengan hasil penelitian Khasanah dan Abdulla (2016) bahwa kemampuan berpikir kritis siswa yang belajar dengan menggunakan model pembelajaran inkuiri lebih baik daripada siswa yang belajar dengan model pembelajaran konvensional. Tidak jauh berbeda hasil penelitian Zaini (2016) menunjukkan bahwa pembelajaran inkuiri terbimbing memberikan pengaruh yang signifikan terhadap hasil belajar siswa, dan kemampuan berpikir kritis siswa yang diajarkan dengan model ini dikategorikan cukup baik.

Namun pada kenyataannya dilapangan bahwa guru lebih memilih menggunakan model pembelajaran konvensional, dimana siswa belajar dengan mendengarkan dan menonton guru dalam pembelajaran matematika (Ayunis, Fauzan, Ardipal, 2018). Pembelajaran matematika yang berlangsung saat ini masih pemebelajaran yang terpusat pada guru di mana guru masih dominan dalam menjelaskan materi pelajaran di kelasdan siswa mendapatkan lebih sedikit kesempatan untuk mengeksplorasi keterampilan untuk mengkomunikasikan ide-ide mereka dalam matematika (Satriawati, Fitriyani, Kadir, 2017).

Matematika sebagai wahana pendidikan tidak hanya dapat digunakan untuk mencapai satu tujuan, misalnya mencerdaskan siswa, tetapi dapat juga untuk membentuk kepribadian (karakter) siswa. Banyak kalangan meyakini bahwa pembelajaran matematika memiliki nilai-nilai tertentu yang amat penting dalam membentuk dan mengembangkan karakter siswa
(Rohana, 2012). Matematika yang selama ini hanya dimaknai sebagai mata pelajaran biasa disekolah, sebenarnya bisa jadi sarana membangun karakter siswa (Dewi, 2015).

Pendidikan karakter pada dasarnya adalah suatu proses yang dibangun dari perilaku masing-masing individu atau orang-orang terbiasa berperilaku baik dan menghargai pentingnya menilai, menginginkan yang baik yang berasal dari mencintai yang baik (Irfan, 2016). Menurut Abu, Mokhtar, Hasan, Suhan (2015) pendidikan karakter adalah upaya yang disengaja untuk mempengaruhi perilaku siswa.

Guru harus mengintegrasikan pendidikan karakter dalam pembelajaran, yaitu dalam tahap perencanaan, pelaksanaan, dan evaluasi pembelajaran. Pada tahap perencanaan, guru memasukkan pendidikan karakter dalam pembelajaran yang akan dilakukan melalui rencana pelaksanaan pembelajaran. Pada tahap pelaksanaan, guru membiasakan siswa untuk melakukan kegiatan yang dapat menumbuh kembangkan karakter siswa. Pada tahap evaluasi, guru mempersiapkan alat yang tepat untuk menguji karakter siswa, misalnya melalui tugas-tugas individu maupun kelompok (Prayogi dan Widodo, 2017).

Namun pada kenyataannya saat ini dalam dunia pendidikan penanaman nilai-nilai yang baik kepada siswa sudah jarang dilakukan, kebanyakan guru hanya terfokus pada peningkatan intelektual siswa, dan kurang memperhatikan karakter siswa (Rahmi, 2013). Selain itu dalam pelaksanaan pembelajaran matematika, guru cenderung mementingkan aspek kognitif dan psikomotorik, sedangkan sedangkan aspek afektif (karakter) kurang tersentuh terutama dalam mengaitkan nilai moral dalam pemecahan masalah matematika. Jika hal ini dibiarkan terus menerus dapat menghasilkan siswa/anak yang berkarakter rendah. Anak yang berkarakter rendah adalah anak yang tingkat perkembangan emosi-sosialnya rendah sehingga anak beresiko atau berpotensi besar mengalami kesulitan belajar, berinteraksi sosial, dan tidak mampu mengontrol diri. Bila kondisi ini terus berlanjut, cepat atau lambat kehancuran pendidikan sudah menunggu di depan mata (Rohana, 2012).

Hal ini juga sejalan dengan observasi awal yang dilakukan di SMP Negeri 3 Langsa, bahwa sebagian guru dalam belajar matematika hanya memfokuskan siswa agar dapat memahami materi yang diajarkan tanpa membangun karakter-karakter pada siswa. Hal ini dapat memberikan dampak yang kurang baik terhadap siswa dalam hal pembentukan karakter. Karajter-karakter umum seperti jujur, disiplin, taat aturan, atau bertanggung jawab sudah semakin hilang. Sebagai bukti lain adalah maraknya upaya-upaya mencontek yang dilakukan siswa hal ini menunjukkan kurangnya kesadaran untuk berlaku jujur.

Berdasarkan hal tersebut peneliti tertarik untuk mengadakan sebuah penelitian lebih lanjut dengan cara memodofikasi tiga model pembelajaran sekaligus dan melihat pengaruhnya terhadap kemampuan berpikir kritis dan kemampuan koneksi matematis siswa, kemudian penulis mengangkatnya dalam sebuah judul penelitian "Pengaruh Model 
Vol. 14, No. 2, Desember 2021

Pembelajaran Inkuiri Terhadap Kemampuan Berpikir Kritis dan Karakter Siswa Kelas VII SMP Negeri 3 Langsa."

\section{KAJIAN TEORITIS}

\section{Kemampuan Berpikir Kritis}

Berpikir kritis didefinisikan sebagai kemampuan untuk menerapkan pengetahuan dan kecerdasan dalam membuat keputusan dan memberikan pendapat tentang isu-isu. Berpikir kritis adalah cara berpikir; artinya, ini meningkatkan kualitas pemikiran tentang subjek, konten atau masalah apa pun, dengan menganalisis, mengakses, dan merekonstruksi pikiran dengan terampil (Osman, Mokhtar, Abu, Mohammad, 2015).

Menurut Nasution, (2018) keterampilan berpikir kritis merupakan suatu keterampilan proses berfikir yang memungkinkan seseorang untuk mengevaluasi atau menyelidiki bukti, asumsi dan logika yang mendasari gagasan orang lain. Selain itu keterampilan berpikir krtitis adalah keterampilan berpikir tingkat tinggi yang dalam mengambil keputusan dapat dipercaya dan dapat dipertanggung jawabkan.

Berdasarkan definisi-definisi yang dikemukakan para ahli di atas, terdapat satu kesamaan mengenai pengertian berpikir kritis, yaitu aktivitas mental yang dilakukan menggunakan langkah-langkah dalam metode ilmiah, yaitu: memahami dan merumuskan masalah, mengumpulkan dan menganalisis informasi yang diperlukan dan dapat dipercaya, merumuskan praduga dan hipotesis, menguji hipotesis secara logis, mengambil kesimpulan secara hati-hati, melakukan evaluasi dan memutuskan sesuatu yang akan diyakini atau sesuatu yang akan dilakukan, serta meramalkan konsekuensi yang mungkin terjadi. Berpikir kritis matematis artinya berpikir kritis dalam bidang matematika.

Jayanti dan Amin (2018) mengidentifikasi bahwa indikator kamampuan berpikir kritis meliputi:

a. Kemampuan interpretasi, yaitu kemampuan siswa dalam memahami suatu permasalahan atau pernyataan yang diberikan. kemampuan ini juga meliputi bagaimana siswa membuat grafik, gambar, dan simbol yang sesuai dengan pernyatan atau pernyataan yang diberikan

b. Kemampuan analisis, analisis siswa meliputi bagaimana siswa dapat mengidentifikasi hubungan dari data atau fakta yang diketahui dengan permasalahan atau pernyataan yang diberikan. Identifikasi hubungan juga dilakukan dengan konsep-konsep yang terkait dengan penyelesaian suatu permasalahan atau hubungan dengan suatu pernyataan. Analisis yang dilakukan oleh siswa menfasilitasi siswa untuk membuat berbagai konjektur yang mungkin

c. Kemampuan inferensi, siswa dinilai dengan bagaimana siswa dapat membuat berbagai konjektur atau kesimpulan dari data-data atau fakta awal yang diketahui secara logis dan jelas. Kelogisan yang dimaksud yaitu bagaimana siswa dapat menghubungkan data yang diketahui dengan konsep-konsep yang terkait dengan pernyataan yang diberikan maupun dengan penyelesaian masalah. Sehingga siswa dapat dengan jelas membuat suatu konjektur atau kesimpulan yang berkaitan dengan suatu permasalahan

\section{Model Pembelajaran Inkuiri}

Menurut Said (2017) pembelajaran berbasis inkuiri adalah jenis pembelajaran yang dicapai melalui proses mencari informasi, pengetahuan dan suatu kebenaran dengan mengajukan sebuah pertanyaan. Hal ini dapat digunakan dalam disiplin ilmu apapun, dan dapat digunakan untuk memecahkan masalah otentik dan menantang menggunakan kombinasi dari ceramah/ presentasi, studi independen, praktikum, kelompok kecil kegiatan kolaboratif dan diskusi kelompok besar. Purwati (2016) menjelaskan pembelajaran inkuiri merupakan pembelajaran yang menuntut peserta didik untuk melakukan aktivitas seperti perencanaan investigasi, melakukan observasi, menganalisis, menafsirkan data, mengusulkan jawaban, merumuskan kesimpulan dan berkomunikasi, pada intinya siswa berperan aktif dalam mengikuti proses pembelajaran.

Berdasarkan beberapa definisi di atas maka dapat disimpulkan bahwa pembelajaran inkuiri merupakan suatu rangkaian kegiatan belajar yang melibatkan secara maksimal seluruh kemampuan siswa untuk mencari dan menyelidiki secara sistematis, kritis, logis, analitis, dan dapat merumuskan sendiri penemuannya dengan penuh percaya diri.

Secara umum proses inkuiri menurut Said (2017), dapat dilakukan melalui beberapa langkah, yaitu:

a. Merumuskan masalah

Pada tahap ini guru membimbing siswa menentukan sebuah masalah yang terkait dengan pelajaran yang disampaikan, kemudian siswa memikirkan sendiri jawabannya.

b. Mengajukan hipotesis

Pada tahap ini guru mebimbing siswa menemukan jawaban sementara masalah yang ditemukan.

c. Mengumpulkan data

Pada tahap ini siswa melakukan eksperimen sederhana.

d. Menguji data berdasarkan data yang ditemukan

Pada tahap ini siswa menguji hasil eksperimen dengan fakta-fakta dan teori yang terkait.

e. Membuat kesimpulan.

Pada tahap ini setelah siswa menemukan hasil, kemudian mempresentasikan hasil diskusinya didepan kelas dan membuat kesimpulan.

\section{Pendidikan Karakter}

Pendidikan karakter adalah suatu sistem penanaman nilai-nilai karakter kepada warga sekolah yang meliputi komponen pengetahuan, kemauan, dan tindakan untuk melaksanakan nilai-nilai tersebut, baik terhadap Tuhan Yang Maha Esa, diri sendiri, sesama, lingkungan, maupun kebangsaan sehingga menjadi insan kamil (Dewi, 2015). Pendidikan karakter adalah pendidikan yang bertujuan mengubah, memperbaiki, dan membentuk sifat-sifat, akhlak dan budi pekerti, tabiat dan watak suatu individu supaya dapat berguna bagi kehidupannya. Nilai-nilai pembentuk karakter yang merupakan hasil kajian empirik Pusat Kurikulum 
Vol. 14, No. 2, Desember 2021

adalah: religius, jujur, toleransi, disiplin, kerja keras, kreatif, mandiri, demokratis, rasa ingin tahu, semangat kebangsaan, cinta tanah air, menghargai prestasi, bersahabat/komunikatif, cinta damai, gemar membaca, peduli lingkungan, peduli sosial, dan tanggung jawab (Rohana, 2012).

Berdasarkan beberapa definsi di atas mengenai pendidikan karakter maka dapat disimpulkan bahwa pendidikan karakter adalah suatu proses untuk meningkatkan kualitas manusia melalui sifat-sifat kejiwaan, budi pekerti dan moral di dalam lingkungannya.

Menurut Rahman (2016) sejumlah nilai untuk pendidikan karakter dalam pembelajaran matematika adalah religius, jujur, toleransi, disiplin, kerja keras, kreatif, mandiri, demokratis, rasa ingin tahu, semangat kebangsaaan, cinta tanah air, menghargai prestasi, bersahabat/ komunikatif, cinta damai, gemar membaca, peduli lingkungan, peduli sosial, tanggung jawab

\section{METODE PENELITIAN}

Jenis penelitian ini adalah penelitian eksperimen semu, yaitu penelitian yang dilakukan untuk memperoleh informasi yang merupakan perkiraan bagi informasi yang dapat diperoleh dengan eksperimen yang sebenarnya dalam keadaan yang tidak memungkinkan untuk mengontrol atau memanipulasi semua variabel yang relevan (Noor, 2015). Desain yang digunakan dalam penelitian ini adalah Randomized Control Group Pretest-Posttest dengan menggunakan pembagian dua kelompok penelitian yaitu kelompok penelitian eksperimen dengan menggunakan model pembelajaran inkuiri, dan kelompok penelitian kontrol tanpa menggunakan model pembelajaran inkuiri. Desain penelitian dapat dilihat pada Tabel 1 berikut ini.

Tabel 1. Desain Penelitian

\begin{tabular}{|l|c|c|c|}
\hline Kelompok & $\begin{array}{c}\text { Pengukuran } \\
\text { (Pretest) }\end{array}$ & Perlakuan & $\begin{array}{c}\text { Pengukuran } \\
\text { (Posttest) }\end{array}$ \\
\hline Eksperimen & $\mathrm{T}_{\mathrm{o}}$ & $\mathrm{X}$ & $\mathrm{T}_{\mathrm{I}}$ \\
\hline Kontrol & $\mathrm{T}_{\mathrm{o}}$ & - & $\mathrm{T}_{\mathrm{I}}$ \\
\hline
\end{tabular}

\section{Keterangan:}

$\mathrm{T}_{\mathrm{o}}$ : Hasil pretest kelas eksperimen dan kelas kontrol

$\mathrm{T}_{\mathrm{I}}$ : Hasil postest kelas eksperimen dan kelas kontrol

$\mathrm{X}$ : Perlakuan menggunakan model pembelajaran inkuiri

Penelitian ini dilakukan di SMP Negeri 3 Langsa yang terletak di Jl. A. Yani, Desa Paya Bujok Seuleumak, Kota Langsa. Populasi dalam penelitian ini adalah seluruh siswa kelas VII SMP Negeri 3 Langsa yang terdiri dari 10 dengan jumlah keseluruhan 320 siswa. Pengambilan sampel pada penelitian ini dengan menggunakan teknik undian, dengan membuat gulungan kertas yang berisi semua populasi dari semua kelas VII yang terdiri dari 10 lokal, kemudian diambil dua gulungan kertas, gulungan kertas yang pertama sebagai kelas eksperimen adalah kelas VII.2 yang berjumlah 32 siswa dan gulungan kertas kedua sebagai kelas kontrol adalah kelas VII.5 yang berjumlah 32 siswa.

Instrumen dalam penelitian ini adalah tes kemampuan berpikir kritis siswa berbentuk esai dan berjumlah 6 soal serta angket karakter siswa yang berjumlah 30 pernyataan. Uji hipotesis statistik yang digunakan adalah ANAVA dua jalur dengan rumus sebagai berikut.

$$
Y_{i j k}=\tau+\alpha_{i}+\beta_{j}+(\alpha \beta)_{i j}+\varepsilon_{i j k}
$$

Dimana $\mathrm{i}=1,2,3 ; \mathrm{j}=1,2 ; \mathrm{k}=1,2,3, \ldots, 32$.

Keterangan

$Y_{i j k} \quad$ : Skor variabel terikat (kemampuan berpikir kritis matematik dan katrakter siswa)

$\tau \quad:$ Skor rata-rata kemampuan berpikir kritis sebenarnya (tanpa perlakuan)

$\alpha_{i} \quad$ : Pengaruh aditif dari KAM ke-i (rendah, sedang, dan tinggi)

$\beta_{j} \quad$ : Pengaruh aditif dari model pembelajaran ke-j

$(\alpha \beta)_{i j}$ : Interaksi antara pembelajaran dan kemampuan awal matematis siswa

$\varepsilon_{i j k} \quad$ : Galat ke-k dalam kombinasi perlakuan (ij)

Secara lengkap prosedur penelitian dilaksanakan dalam penelitian ini, disajikan dalam bentuk langkahlangkah atau alur penelitian berikut ini:

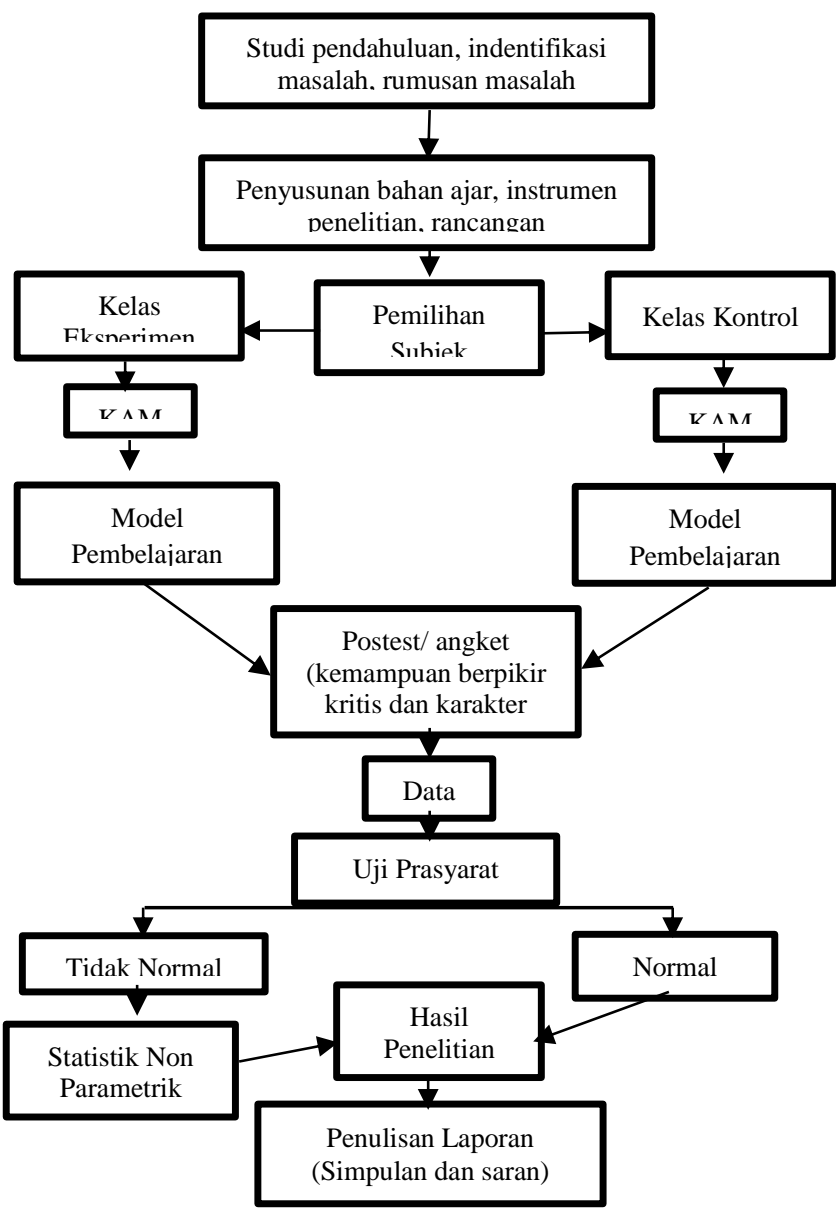

Gambar 1. Tahapan Alur Penelitian 


\section{HASIL PENELITIAN}

1. Data Kemampuan Awal Matematis Siswa

Pengelompokkan kemampuan awal matematika siswa (tinggi, sedang, dan rendah) dibentuk berdasarkan kriteria klasifikasi kemampuan awal matematika siswa. Hasil pengelompokkan dijasikan pada Tabel 2 berikut :

Tabel 2. Pengelompokkan KAM Siswa

\begin{tabular}{rccc}
\hline \multirow{2}{*}{ KAM } & \multirow{2}{*}{ Statistik } & \multicolumn{2}{c}{ Kelas } \\
\cline { 2 - 4 } & & Eksperimen & Kontrol \\
\hline \multirow{2}{*}{ Tinggi } & $\mathrm{N}$ & 9 & 8 \\
\cline { 2 - 4 } & $\overline{\boldsymbol{x}}$ & 46,78 & 44,78 \\
\cline { 2 - 4 } & $\mathrm{s}$ & 7,74 & 5,12 \\
\hline \multirow{3}{*}{ Sedang } & $\mathrm{N}$ & 14 & 18 \\
\cline { 2 - 4 } & $\overline{\boldsymbol{x}}$ & 46,57 & 43,55 \\
\cline { 2 - 4 } & $\mathrm{s}$ & 4,55 & 2,59 \\
\hline \multirow{3}{*}{ Rendah } & $\mathrm{N}$ & 9 & 6 \\
\cline { 2 - 4 } & $\overline{\boldsymbol{x}}$ & 37,67 & 38,67 \\
\cline { 2 - 4 } & $\mathrm{s}$ & 0,71 & 1,03 \\
\hline
\end{tabular}

Berdasarkan Tabel 2 di atas diperoleh pada kelas eksperimen kemampuan awal matematika siswa untuk kategori rendah 9 orang siswa, sedangkan pada kelas kontrol sebanyak 9 orang siswa. Kemampuan awal matematika untuk kategori sedang pada kelas eksperimen sebanyak 14 siswa dan pada kelas kontrol sebanyak 18 siswa. Sedangkan kemampuan awal matematika siswa untuk kategori tinggi pada kelas eksperimen sebanyak 9 siswa dan pada kelas kontrol sebanyak 8 siswa.

2. Deskriptif Hasil Pos Tes Kemampuan Berpikir Kritis Siswa Berdasarkan KAM

Rata-rata pos tes kemampuan berpikir kritis matematika siswa berdasarkan KAM disajikan pada Tabel 3 berikut.

Tabel 3. Rata-Rata Pos Tes Kemampuan Berpikir Kritis Matematika Berdasarkan KAM

\begin{tabular}{|c|c|c|c|c|}
\hline & \multirow{2}{*}{ KAM } & \multirow{2}{*}{ Statistik } & \multicolumn{2}{|c|}{ Kelas } \\
\hline & & & Eksperimen & Kontrol \\
\hline \multirow{9}{*}{$(\mathrm{KBK})$} & \multirow{3}{*}{ Tinggi } & $\mathrm{N}$ & 9 & 8 \\
\hline & & $\bar{x}$ & 86,88 & 85,62 \\
\hline & & $\mathrm{s}$ & 5,44 & 5,34 \\
\hline & \multirow{3}{*}{ Sedang } & $\mathrm{N}$ & 14 & 17 \\
\hline & & $\bar{x}$ & 83,78 & 73,76 \\
\hline & & $\mathrm{s}$ & 6,07 & 6,27 \\
\hline & \multirow{3}{*}{ Rendah } & $\mathrm{N}$ & 9 & 7 \\
\hline & & $\bar{x}$ & 65,55 & 67,28 \\
\hline & & $\mathrm{s}$ & 6,50 & 5,31 \\
\hline
\end{tabular}

Tabel 3 memperlihatkan bahwa rata-rata dan standar deviasi kemampuan berpikir kritis matematika kelas eksperimen dengan kelompok KAM tinggi adalah sebesar 86,88 dan 5,44 untuk kelas eksperimen, serta 85,62 dan 5,34 untuk kelas kontrol. Untuk ratarata dan standar deviasi dengan kelompok KAM sedang sebesar 83,78 dan 6,07, serta 73,76 dan 6,27. Sedangkan untuk rata-rata dan standar deviasi dengan kelompok KAM rendah sebesar 65,66 dan 6,50, serta 67,28 dan 5,31 .

3. Deskripsi Karakter Siswa Berdasarkan KAM Rata-rata pos tes karakter siswa berdasarkan KAM disajikan pada Tabel 4 berikut.

Tabel 4. Rata-Rata Angket Karakter Siwa Berdasarkan KAM

\begin{tabular}{llccc}
\hline \multirow{2}{*}{ KAM } & \multirow{2}{*}{ Statistik } & \multicolumn{2}{c}{ Kelas } \\
\cline { 3 - 5 } & \multirow{3}{*}{ Tinggi } & & Eksperimen & Kontrol \\
\cline { 3 - 5 } & & $\mathrm{N}$ & 9 & 8 \\
\cline { 3 - 5 } Karakter & \multirow{3}{*}{ Sedang } & $\overline{\boldsymbol{x}}$ & 89,66 & 86,80 \\
\cline { 3 - 5 } & & $\mathrm{s}$ & 3,74 & 5,45 \\
\cline { 3 - 5 } & & $\mathrm{N}$ & 14 & 17 \\
\cline { 3 - 5 } & \multirow{3}{*}{ Rendah } & $\mathrm{x}$ & 89,21 & 86,66 \\
\cline { 3 - 5 } & & $\mathrm{N}$ & 5,33 & 3,88 \\
\cline { 3 - 5 } & & $\overline{\boldsymbol{x}}$ & 96,00 & 7 \\
\cline { 3 - 5 } & & $\mathrm{s}$ & 7,08 & 6,83 \\
\hline
\end{tabular}

Tabel 4. memperlihatkan bahwa rata-rata dan standar deviasi karakter siswa kelas eksperimen dengan kelompok KAM tinggi adalah sebesar 89,66 dan 3,74 untuk kelas eksperimen, serta 86,80 dan 5,54 untuk kelas kontrol. Untuk rata-rata dan standar deviasi dengan kelompok KAM sedang sebesar 89,21 dan 5,33 , serta 86,66 dan 3,88. Sedangkan untuk rata-rata dan standar deviasi dengan kelompok KAM rendah sebesar 86,00 dan 7,08, serta 85,00 dan 6,83.

\section{Uji Hipotesis}

Pengujian hipotesis yang dirumuskan dianalisis dengan menggunakan analisis varian dua jalur menggunakan statistik $\mathrm{F}$ dengan rumus yang telah ditetapkan. Hasil perhitungan analisis uji hipotesis dapat dilihat pada Tabel 5 sebagai berikut.

Tabel 5. Tabel Analisis Varians Dua Arah Hipotesis 1 dan 3

Tests of Between-Subjects Effects

Dependent Variable:KBK

\begin{tabular}{|c|c|c|c|c|c|}
\hline Source & $\begin{array}{l}\text { Type III } \\
\text { Sum of } \\
\text { Squares }\end{array}$ & df & $\begin{array}{l}\text { Mean } \\
\text { Square }\end{array}$ & $\mathrm{F}$ & Sig. \\
\hline $\begin{array}{l}\text { Corrected } \\
\text { Model }\end{array}$ & $4125.779^{a}$ & 5 & 825.156 & 23.302 & .000 \\
\hline Intercept & 345430.768 & 1 & 345430.768 & $9.755 \mathrm{E} 3$ & .000 \\
\hline KAM & 3279.735 & 2 & 1639.868 & 46.310 & .000 \\
\hline Model & 147.168 & 1 & 147.168 & 4.156 & .046 \\
\hline $\begin{array}{l}\text { KAM * } \\
\text { Model }\end{array}$ & 430.120 & 2 & 215.060 & 6.073 & .004 \\
\hline Error & 2053.831 & 58 & 35.411 & & \\
\hline Total & 389805.000 & 64 & & & \\
\hline $\begin{array}{l}\text { Corrected } \\
\text { Total }\end{array}$ & 6179.609 & 63 & & & \\
\hline
\end{tabular}

a. R Squared $=, 668($ Adjusted R Squared $=, 639)$

Berdasarkan Tabel 5 di atas terlihat bahwa nilai sig model sebesar 0,046 dimana nilai tersebut lebih kecil 
Vol. 14, No. 2, Desember 2021

dari $0,05(0,045<0,05)$, hal ini berarti Ho ditolak. Sehingga dapat disimpulkan bahwa terdapat pengaruh model pembelajaran inkuiri terhadap kemampuan berpikir kritis siswa kelas VII SMP Negeri 3 Langsa. untuk nilai sig KAM sebesar 0,000 dimana nilai tersebut lebih kecil dari $0,05(0,045<0,05)$, hal ini berarti terdapat pengaruh KAM dengan kelompok tinggi, sedang dan rendah terhadap kemampuan berpikir kritis siswa kelas VII SMP Negeri 3 Langsa.

Selanjutnya nilai sig KAM*Model sebesar 0,004 dimana nilai tersebut lebih kecil dari 0,05 $(0,004<$ $0,05)$ hal ini berarti cukup syarat untuk menolak Ho. Atau dengan kata lain Terdapat interaksi antara model pembelajaran dan KAM terhadap kemampuan berpikir kritis siswa kelas VII SMP Negeri 3 Langsa. Interaksi antara model pembelajaran dan KAM terhadap kemampuan berpikir kritis siswa tersebut juga dapat dilihat pada Gambar 4.4 sebagai berikut.

\section{Estimated Marginal Means of KBK}

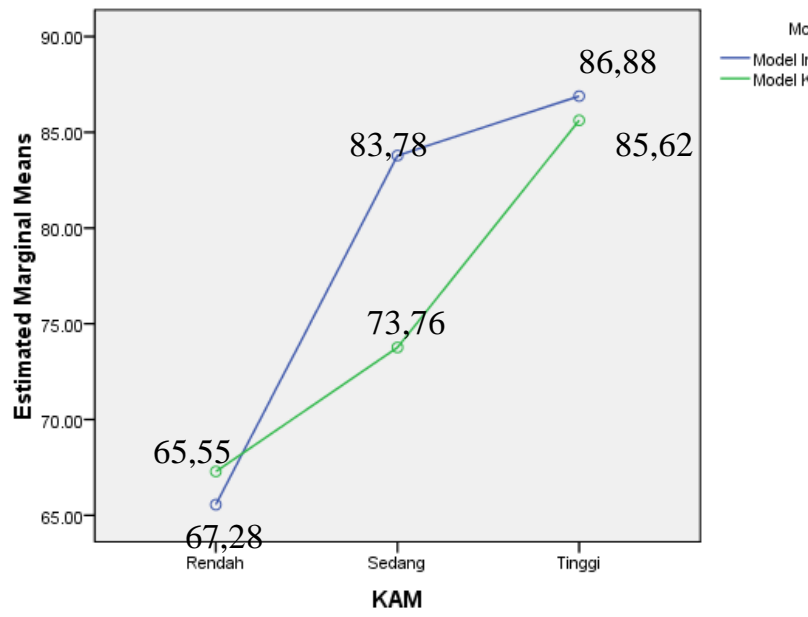

Gambar 2. Interaksi Antara Model Pembelajaran dan KAM Terhadap Kemampuan Berpikir Kritis Siswa

Dari Gambar 2 terlihat bahwa pada KAM kategori rendah pada kelas eksperimen dengan model pembelajaran inkuiri memiliki rata-rata 65,55, sedangkan pada kelas kontrol memiliki rata-rata 67,28. Selisih rata-rata kemampuan berpikir kritis antara kelas eksperimen dan kelas kontrol adalah sebesar 1,73. Pada KAM kategori sedang pada kelas eksperimen dengan model pembelajaran inkuiri memiliki rata-rata 83,78, sedangkan pada kelas kontrol memiliki rata-rata 73,76. Selisih rata-rata kemampuan berpikir kritis antara kelas eksperimen dan kelas kontrol adalah sebesar 10,02. Pada KAM kategori tinggi pada kelas eksperimen dengan model pembelajaran inkuiri memiliki rata-rata 86,88 , sedangkan pada kelas kontrol memiliki rata-rata 85,62 . Selisih rata-rata kemampuan berpikir kritis antara kelas eksperimen dan kelas kontrol adalah sebesar 1,62. Selanjutnya dari Tabel 5 tampak bahwa besar pengaruh variabel KAM, model, dan interaksi KAM dan model terhadap kemampuan berpikir kritis matematika siswa adalah sebesar $66,8 \%$.
Pengujian hipotesis selanjutnya dapat dilihat pada Tabel 6 berikut.

Tabel 6. Tabel Analisis Varians Dua Arah Hipotesis 2 dan 4

Tests of Between-Subjects Effects

Dependent Variable:Karakter

\begin{tabular}{|c|c|c|c|c|c|}
\hline Source & $\begin{array}{l}\text { Type III } \\
\text { Sum of } \\
\text { Squares }\end{array}$ & df & $\begin{array}{c}\text { Mean } \\
\text { Square }\end{array}$ & $\mathrm{F}$ & Sig. \\
\hline $\begin{array}{l}\text { Corrected } \\
\text { Model }\end{array}$ & $251.710^{\mathrm{a}}$ & 5 & 50.342 & 1.314 & .271 \\
\hline Intercept & 639457.993 & 1 & 639457.993 & $1.670 \mathrm{E} 4$ & .000 \\
\hline KAM & 30.443 & 2 & 15.221 & .397 & .674 \\
\hline Model & 163.879 & 1 & 163.879 & 4.279 & .043 \\
\hline $\begin{array}{l}\text { KAM * } \\
\text { Model }\end{array}$ & 47.998 & 2 & 23.999 & .627 & .538 \\
\hline Error & 2221.290 & 58 & 38.298 & & \\
\hline Total & 709754.000 & 64 & & & \\
\hline
\end{tabular}

Corrected $2473.000 \quad 63$

Total

a. R Squared $=, 102($ Adjusted R Squared $=, 024)$

Berdasarkan Tabel 6 di atas terlihat bahwa nilai sig model sebesar 0,043 dimana nilai tersebut lebih kecil dari $0,05(0,043<0,05)$, hal ini berarti Ho ditolak. Sehingga dapat disimpulkan bahwa terdapat pengaruh model pembelajaran inkuiri terhadap karakter siswa kelas VII SMP Negeri 3 Langsa. Selanjutnya nilai sig $\mathrm{KAM}^{*}$ Model sebesar 0,538 dimana nilai tersebut lebih besar dari $0,05(0,538>0,05)$ hal ini berarti cukup syarat untuk menolak Ha. Atau dengan kata lain tidak terdapat interaksi antara model pembelajaran dan KAM terhadap kemampuan berpikir kritis siswa kelas VII SMP Negeri 3 Langsa. Interaksi antara model pembelajaran dan KAM terhadap karakter siswa tersebut juga dapat dilihat pada Gambar 4.4 sebagai berikut.

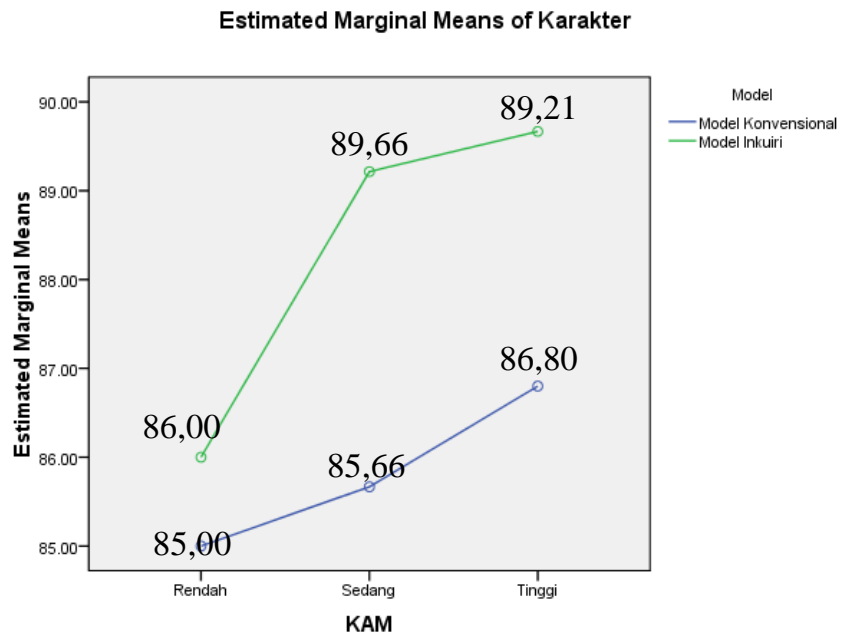

Gambar 3. Interaksi Antara Model Pembelajaran dan KAM Terhadap Karakter Siswa 
Vol. 14, No. 2, Desember 2021

\begin{tabular}{|c|c|}
\hline 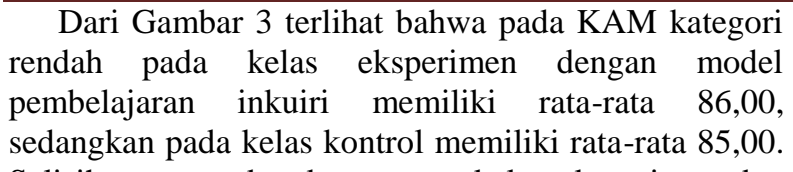 & $\begin{array}{l}\text { hasil penelitian Maryam, Kusmiyati, Merta, Artasya } \\
\text { (2019) menunjukkan bahwa model pembelajaran } \\
\text { inkuiri berpengaruh dalam meningkatkan keterampilan } \\
\text { berpikir kritis siswa. }\end{array}$ \\
\hline
\end{tabular}
kelas kontrol adalah sebesar 1. Pada KAM kategori sedang pada kelas eksperimen dengan model pembelajaran inkuiri memiliki rata-rata 89,21, sedangkan pada kelas kontrol memiliki rata-rata 85,66. Selisih rata-rata karater antara kelas eksperimen dan kelas kontrol adalah sebesar 3,55. Pada KAM kategori tinggi pada kelas eksperimen dengan model pembelajaran inkuiri memiliki rata-rata 89,66, sedangkan pada kelas kontrol memiliki rata-rata 86,80. Selisih rata-rata karakter antara kelas eksperimen dan kelas kontrol adalah sebesar 2,86. Selanjutnya dari Tabel 6 tampak bahwa besar pengaruh variabel KAM, model, dan interaksi KAM dan model terhadap karakter siswa adalah sebesar $10,2 \%$.

\section{PEMBAHASAN}

1. Pengaruh Model Pembelajaran Inkuiri Terhadap Kemampuan Berpikir Kritis Siswa Kelas VII SMP Negeri 3 Langsa

Berdasarkan hasil pengujian diperoleh bahwa nilai sig model sebesar 0,046 dimana nilai tersebut lebih kecil dari $0,05(0,045<0,05)$, hal ini berarti Ho ditolak. Sehingga dapat disimpulkan bahwa terdapat pengaruh model pembelajaran inkuiri terhadap kemampuan berpikir kritis siswa kelas VII SMP Negeri 3 Langsa. Pembelajaran inkuiri merupakan rangkaian kegiatan pembelajaran yang menekankan pada proses berpikir kritis dan analitis untuk mencari dan menemukan jawaban sendiri, jawaban dari suatu masalah yang dipertanyakan. Pengajaran berbasis inkuiri merupakan model pengajaran yang telah dikembangkan untuk tujuan mengajarkan siswa cara berpikir (Eko Saputra, 2017). Dalam pembelajaran inkuiri siswa terlibat secara aktif dan mandiri dalam membuat, menguji serta mengevaluasi hipotesis. Guru hanya berperan sebagai pemberi petunjuk yang mengarahkan siswa terhadap tujuan pembelajaran yang disusun dalam lembar kerja yang diberikan kepada siswa (Pinasti, 2019). Pembelajaran inkuiri dirancang untuk mengajak siswa secara langsung ke dalam proses ilmiah ke dalam waktu yang relatif singkat. Pembelajaran dengan model inkuiri dapat meningkatkan pemahaman sains, produktif dalam beripikir, dan siswa menjadi terampil dalam memperoleh dan menghanalisis informasi (Al-Tabany, 2017).

Hasil penelitian di atas juga di dukung oleh hasil penelitian Khasanah dan Abdulla (2016) bahwa kemampuan berpikir kritis siswa yang belajar dengan menggunakan model pembelajaran inkuiri lebih baik daripada siswa yang belajar dengan model pembelajaran konvensional. Tidak jauh berbeda hasil penelitian Zaini (2016) menunjukkan bahwa pembelajaran inkuiri terbimbing memberikan pengaruh yang signifikan terhadap hasil belajar siswa, dan kemampuan berpikir kritis siswa yang diajarkan dengan model ini dikategorikan cukup baik. Kemudian

\section{Pengaruh Model Pembelajaran Inkuiri Terhadap Karakter Siswa Kelas VII SMP Negeri 3 Langsa \\ Berdasarkan hasil pengujian diperoleh bahwa nilai sig model sebesar 0,043 dimana nilai tersebut lebih kecil dari $0,05(0,043<0,05)$, hal ini berarti Ho ditolak. Sehingga dapat disimpulkan bahwa terdapat pengaruh model pembelajaran inkuiri terhadap karakter siswa kelas VII SMP Negeri 3 Langsa. Matematika sebagai wahana pendidikan tidak hanya dapat digunakan untuk mencapai satu tujuan, misalnya mencerdaskan siswa, tetapi dapat juga untuk membentuk kepribadian (karakter) siswa. Hubungan antara matematika dan pembentukan karakter seperti yang diungkapkan oleh Wasono dalam Hudha, Ekowati, Hasamah (2014) adalah ketika seseorang belajar mengeksplorasi matematika dan melakukan penelitian, maka dia akan dididik untuk mendapatkan karakter dasar peneliti dalam bentuk hati nurani, jujur, memiliki integritas, visioner, terbuka, objektif, semangat kerja sama terhadap orang lain dan pelajar.}

3. Interaksi Antara Model Pembelajaran dan KAM Terhadap Kemampuan Berpikir Kritis Siswa Kelas VII SMP Negeri 3 Langsa

Berdasarkan hasil pengujian diperoleh diperoleh nilai sig $\mathrm{KAM}^{*}$ Model sebesar 0,004 dimana nilai tersebut lebih kecil dari $0,05(0,004<0,05)$ hal ini berarti cukup syarat untuk menolak Ho. Atau dengan kata lain Terdapat interaksi antara model pembelajaran dan KAM terhadap kemampuan berpikir kritis siswa kelas VII SMP Negeri 3 Langsa. Berdasarkan grafik interaksi model pembelajaran dan KAM terhadap kemampuan berpikir kritis dapat disimpulkan bahwa model pembelajaran inkuiri lebih cocok diterapkan untuk siswa dengan KAM sedang dan tinggi. Hal ini terjadi karena pada kelompok siswa dengan KAM sedang dan tinggi dapat terlibat secara aktif pada proses berpikir kritis membangun pengetahuan baru dan menemukan solusi dari masalah matematis yang disajikan. Pada model pembelajaran inkuiri siswa degan KAM sedang dan tinggi dapat melakukan tahapan-rahapan model dengan baik, dimulai dari membuat rumusan masalah, menduga jawaban sementara atau membuat hipotesis, kemudian megumpulkan data terkait dengan masalah yang telah diberikan, menganalisis hasil akhir sampai dengan menarik kesimpulan. Akibatnya kemampuan berpikir kritis siswa kelompok siswa dengan KAM sedang dan tinggi menjadi lebih baik.

Sedangkan model pembelajaran inkuiri ini kurang efektif digunakan kepada siswa yang memiliki KAM rendah. Alasannya adalah pada pelaksanaannya kegiatan pembelajaran inkuiri didominasi oleh kelompok siswa sedang dan tinggi. Siswa yang memiliki KAM rendah cenderung bertindak pasif, menjadi pendengar yang baik, membiarkan teman lain mengambil kendali atas kegiatan diskusi kelompok, 
mempercayakan penyelesaiakan tugas kepada temanb yang memiliki KAM sedang dan tinggi dan meminta penjlasan atas penyelesaian tugas yang telah dihasilkan oleh teman yang memiliki KAM sedang dan tinggi.

4. Terdapat Interaksi Antara Model Pembelajaran dan KAM Terhadap Karakter Siswa Kelas VII SMP Negeri 3 Langsa

Berdasarkan hasil pengujian diperoleh diperoleh nilai sig KAM*Model sebesar 0,538 dimana nilai tersebut lebih besar dari $0,05(0,538>0,05)$ hal ini berarti cukup syarat untuk menolak Ha. Atau dengan kata lain tidak terdapat interaksi antara model pembelajaran dan KAM terhadap kemampuan berpikir kritis siswa kelas VII SMP Negeri 3 Langsa.

Beberapa faktor yang menyebabkan tidak terdapat interaksi antara KAM dan model pembelajaran terhadap karakter siswa adalah pengelompokan belajar siswa, hal ini kemungkinan disebabkan pengelompokkan yang dilakukan saat pembelajaran belum mencerminkan konsep belajar kelompok yang sesuai dengan yang diharapkan. Hal tersebut sangat mungkin terjadi karena pengelompokan siswa berdasarkan KAM tidak benar-benar menggambarkan KAM siswa yang sebenarnya. Selain faktor KAM adakemungkinan faktor lain yang menyebabkan tidak terjadinya interaksi yaitu perbedaan model pembelajaran yang digunakan. Dalam penelitian ini, model pembelajaran yang digunakan adalah model pembelajaran Inkuiri, secara teoritis dalam model pembelajaran inkuiri mempunyai karakteristik kemungkinan terjadi interaksi antara anggota kelompok dan guru berperan sebagai pemberi bantuan yang proporsional, memotivasi siswa agar memanfaatkan kelompok sebagai sarana diskusi dan bertukar pendapat/ide sehingga yang pada akhirnya dapat mampu mengembangkan potensi siswa. Selain itu kemungkinan lain yang menyebabkan tidak terjadinya interaksi adalah LKPD yang digunakan dalam penelitian dikembangkan berdasarkan karakter tetapi dikembangkan berdasarkan aspek kognitif. Hal lain yang memungkinkan tidak terjadinya interaksi antara KAM dan model pembelajaran terhadap karakter siswa yaitu pada saat pengisian angket siswa tidak teliti.

\section{KESIMPULAN}

Berdasarkan hasil analisis dan pembahasan dalam penelitian ini, dikemukakan beberapa kesimpulan sebagai berikut :

1. Terdapat pengaruh model pembelajaran inkuiri terhadap kemampuan berpikir kritis siswa kelas VII SMP Negeri 3 Langsa

2. Terdapat pengaruh model pembelajaran inkuiri terhadap karakter siswa kelas VII SMP Negeri 3 Langsa

3. Terdapat interaksi antara model pembelajaran dan KAM terhadap kemampuan berpikir kritis siswa kelas VII SMP Negeri 3 Langsa

4. Tidak terdapat interaksi antara model pembelajaran dan KAM terhadap karakter siswa kelas VII SMP Negeri 3 Langsa

\section{UCAPAN TERIMA KASIH}

Pada kesempatan ini, penulis mengucapkan terima kasih yang tulus dan penghargaan yang setinggitingginya kepada semua pihak yang telah membantu penulis, kepada keluarga yang telah mendukung penulis dalam segala hal. Bapak Dr. Mulyono, M.Si selaku dosen pembimbing I, bapak Prof. Dr. Edi Syahputra, M.Pd selaku dosen pembimbing II, Kepala Sekolah dan guru-guru serta staf administrasi SMP Negeri 3 Langsa yang telah memberikan izin dan kesempatan kepada penulis untuk melakukan penelitian di sekolah tersebut.

\section{REFERENSI}

Abu, Mokhtar, Hasan, Suhan. 2015. How to Develop Character Education of madrassa Srudents in Indonesia. Journal of Education and Learning. Vol.9, No.1: 79-86

Al-Tabany, Trianto Ibn Badar. 2015. Model-Model Pembelajaran Inovatif. Jogjakarta : Ar ruzz Media.

Ayu Latifa, Ayu Latifa, Putu Verawati, Harjono. 2017. Pengaruh Model Learning Cycle (Engange, Explore, Explain, Elaboration and Evaluate), Terhadap Kemmapuan Berpikir Kritis Peserta Didik Kelas X MAN 1 Mataram. Jurnal Pendidikan Fisika dan Teknologi. Vol.3, No.1: 61-67

Ayunis, Fauzan, Ardipal. 2018. The Influence of Active Knowledge Sharing Strategies and Initial Ability of Students' Mathematical Ability. Preceeding IcoIE. Vol.178: 221-225

Dewi, Yustifa Kumala. 2015. Pendidikan karakter Dalam Pembelajaran Matematika. Jurnal Math Didactic. Vol.1, No.2: 117-124

Eko Saputra, Teguh Budi Rajarjo. 2016. Desain Riset Perangkat Pembelajaran Menggunakan Media Kit Listrik Yang Dilengkapi PhEt Berbasis Inkuiri Untuk Melatihkan Keterampilan Proses Sains. Unnes Science Education Journal. Vol.5, No.3: 1331-1342

Hudha, Ekowati, Hasamah. 2014. Character Education Model In Mathematics And Natural Science Learning At Muhammadiyah Junior High School. International Journal Of Education, Learning \& Development. Vol.2, No.4: 33-47

Irfan, Muhammad. 2016. Role of Learning Mathematics in the Character Building. International Conference On Education (ICE2): 599-04

Jayanti, Ana dan Bunga Dara Amin. 2018. Pengaruh pembelajaran Inkuiri Terbimbing Terhadap Kemampuan Berpikir Kritis Peserta Didik Kelas XI MIA SMA Negeri 2 BARRU. Vol.14, No.1:23-28

Khasanah, Ummi dan Wahyuddin Abdulla. 2016. Scientific Inquiry For Critical Thinking Ability And Self Confidence Islamic Junior Students. International Conference on Mathematics, Science and Education. p: 176-179

Maryam, Kusmiyati, Merta, Artasya. 2019. Pengaruh Model Pembelajaran inkuiri Terhadap Keterampilan Berpikir Kritis Siswa Kelas XI MA 
Vol. 14, No. 2, Desember 2021

MAN 2 Mataram. J.Pijar MIPA. Vol.14, No.3: 206-213

Osman, Mokhtar, Abu, Mohammad. 2015. Pertinent Eelemnts of Critical Thinking and Mathematical Thinking Used by Practicing Civil Engineers. International Journal of Science : Basic and Applied Research. Vol. 23, No.2: 381-395

Pinasti, Agnis. 2019. Efektivitas Model Pembelajaran Inkuiri Terbimbing Untuk Meningkatkan Kemampuan Pemecahan Masalah Matematis Siswa (Studi pada Siswa Kelas VII SMP Negeri 1 Tanjung Bintang Semester Genap Tahun Pelajaran 2018/2019). Skripsi Tidak Diterbitkan. Lampung : UNILA.

Prayogi dan Widodo. 2017. Kemampuan Berpikir Kritis Ditinjau Dari Karakter Tanggung Jawab Pada Model Braind Based Learning. Jurnal UJMER. Vol.6, No.1: 89-95

Purwati, R.P. 2014. Penerapan Model Pembelajaran Inkuiri Terbimbing Pada Materi Sistem Ekskresi Kulit Untuk Meningkatkan Keterampilan Proses Sains Siswa Kelas XI SMA. Proceeding Biology Education Conference. Vol.13, No.1: 325-329

Putu Verawati, Wahyudi, Taufik. 2018. Efek dan Kontribusi Penggunaan Strategi Konflik Kognitif Berbasis Model Inkuiri Terhadap Peningkatan Kemampuan Berpikir Kritis Mahasiswa. Jurnal Pendidikan Fisika dan Teknologi. Vol.4, No.2: 232239

Rahman, Abdul. 2016. Pendidikan Karakter Dalam Pembelajaran Matematika. Jurnal Aksioma. Vol.5, No.3: 1-7

Rahmi. 2013. Kontribusi Matematika dalam Pembentukan Karakter Siswa. Jurnal Ekotrans. Vol.12, No.1: 31-38

Rohana. 2012. Peran Pendidikan Matematika Sebagai Wahana Pembangun Karakter Bangsa. Jurnal Prosiding Seminar Nasional Matematika dan Pendidikan Matematika. ISBN : 978-979-16353-87: 999-1008

Rosmaiyadi. 2017. Analisis Kemampuan Bepikir Kritis Matematis Siswa Dalam Learning Cycle 7E Berdasrakan Gaya Belajar. Jurnal Aksioma. Vol.6, No.1: 12-19

Rozi Nasution, Sari Wahyuni. 2018. Penerapan Model Inkuiri Terbimbing (Guided Inquiry) Dalam Meningkatkan Kemampuan Berpikir Kritis Pada Pembelajaran Fisika. Journal Education and Development. Vol.3, No.1: 82-88

Said dan Rusli. 2017. Peranan Model Pembelajaran Inkuiri Terbimbing Terhadap Keterampilan Proses Sains Pada Peserta Didik Kelas X SMA Negeri 2 Polewali. Jurnal Sains dan Pendidikan Fisika (JSPF). Vol.13, No.1: 255-262

Samosir, Rosauli Novalina. 2018. Perbandingan Kemampuan Bepikir Kritis Siswa Yang Diajar Dengan Menggunakan Model Discovery Learning dan Kooperatif Tipe Make A Match Dengan Media Kartu Soal Pada Materi Teorema Pythagoras. Jurnal Inspiratif. Vol.1, No.1: 24-36
Satriawati, Fitriyani, Kadir. 2017. The effect of The Learning Cell Model on Students' Mathemaical Communication Skills. Proceeding ICEMS. Vol.115: 77-82

Simbolon, Manullang, Surya dan Syahputra. 2017. The Effort to Improving the Critical Thinking Student's Ability Through Problem Solving Learning Strategy by Using Macromedia Flash at SMP Negeri 5 Padang Bolak. Novelty Journals. Vol.4, No.1: 82-90

Sugianto, Suryandari, Age. 2020. Efektivitas Model Pembelajaran Inkuiri Terhadap Kemandirian Belajar Siswa Di Rumah. Jurnal Inovasi Penelitian. Vol.1, No.3: 159-170

Sundahry, Fitria, Rakimahwati. 2018. The Effect Reciprocal Teaching Strategy Of Critical Thinking Skilss In Learning Tematic Vlass V. Preceeding ICESST. Doi: https://doi.org/10.29210/20181118: 816-822

Temel, Senar. 2014. The Effects Of Problem-Based Learning On Preservice Teachers Critical Thinking Dispositions And Perceptions Of problem-Solving Ability. South African Journal of Education. Vol.34, No.1: 1-20

Zaini, Muhammad. 2016. Guided Inquiry Based Learning on the Concept of Ecosystem Toward Learning Outcomes and Critical Thinking Skills of High School Students. Journal IOSR-JRME. Vol.6, No.6: 50-55 